\title{
KRZYSZTOF HELINIAK
}

Samorządowe Kolegium Odwoławcze w Rzeszowie helin77@tlen.pl

ORCID: 0000-0002-6382-108X

PAWEŁ MAJKA

Uniwersytet Rzeszowski

pmajka@univ.rzeszow.pl

ORCID: 0000-0003-4315-4133

\section{Glosa do wyroku WSA w Rzeszowie z dnia 15 grudnia 2015 r. (I SA/Rz 1090/15) ${ }^{1}$}

\section{Commentary to the judgment of the Voivodship Administrative Court of 15th December 2015 (I SA/Rz 1090/15)}

Streszczenie. Przedmiotem opracowania jest krytyczna analiza tezy z uzasadnienia wyroku WSA w Rzeszowie z dnia 15 grudnia 2015 r. (I SA/Rz 1090/15), zgodnie z którą zwolnienia z podatku od nieruchomości stanowią przywilej, który jest wyjątkiem od ogólnej zasady powszechności opodatkowania, dlatego zwol-

1 CBOSA; wyrokiem NSA z dnia 20 kwietnia 2018 r., II FSK 1041/16, oddalono skargę kasacyjną od glosowanego wyroku. 
nienie musi być interpretowane ściśle. W ocenie autorów teza ta nie znajduje oparcia w treści obowiązujących przepisów oraz aktualnych poglądów doktryny na problem interpretacji przepisów.

Słowa kluczowe: podatek od nieruchomości; zwolnienia podatkowe; przywileje podatkowe; wykładnia przepisów; uzasadnienie wyroku.

Abstract. This study contains a critical analysis of the judgment of the Voivodship Administrative Court in Rzeszów of 15th December 2015 (I SA/Rz 1090/15). In the Authors' opinion the court wrongly interpreted the need for a strict interpretation of tax law in respect of the provisions implementing tax exemptions. In this study Authors claim that this view of the judges is not supported by the content of the current regulations and by doctrinal views.

Keywords: real estate tax; tax exemptions; tax reliefs; tax privileges; interpretations of tax law; reasoning of judgement.

Teza: Należy podkreślić, że przepis art. 7 ust. 1 pkt 5 u.p.o.l. zawiera przywilej, który jest wyjątkiem od ogólnej zasady powszechności opodatkowania. Dlatego, jak to jest utrwalone w doktrynie i orzecznictwie, zwolnienie musi być interpretowane ściśle, a co za tym idzie, to na stronie spoczywa ciężar wykazania przesłanek umożliwiających skorzystanie z przywileju zwolnienia z podatku.

\section{1.}

Glosowane orzeczenie dotyczy problematyki zwolnień w podatku od nieruchomości gruntów, budynków lub ich części zajętych na potrzeby prowadzenia przez stowarzyszenia statutowej działalności wśród dzieci i młodzieży w zakresie kultury fizycznej i sportu. Spór pomiędzy podatnikiem a organami podatkowymi dotyczył kwestii prawidłowości w zakresie ustaleń faktycznych w kilku aspektach, w tym m.in. kwestii faktycznego wykorzystywania nieruchomości dla realizacji celów stowarzyszenia oraz podstaw do uznania właściciela nieruchomości za podatnika. Jednocześnie głównym problemem wymagającym skomentowania jest teza 
wyroku sądu I instancji odnosząca się do zasad wykładni przepisów regulujących zwolnienia podatkowe. Teza ta stanowiła bowiem następnie podstawę do uznania za prawidłowe ustaleń organów podatkowych, co do których istniały wątpliwości w zakresie naruszenia przepisów przewidujących zasadę prawdy obiektywnej (art. 122, art. 187 § 1 i art. 191 ustawy z 29 sierpnia 1997 r. Ordynacja podatkowa²).

\section{2.}

Stan faktyczny sprawy dotyczył opodatkowania nieruchomości - działki oraz usytuowanego na niej budynku hali sportowej. Nieruchomości zostały użyczone przez podatnika będącego przedsiębiorcą stowarzyszeniu, którego celem statutowym była działalność wśród dzieci i młodzieży w zakresie kultury fizycznej i sportu, co w ocenie podatnika powinno skutkować zwolnieniem z podatku. Istota sporu w sprawie rozstrzygniętej glosowanym wyrokiem sprowadzała się więc do ustalenia, czy odnośnie do całej powierzchni budynku użyczonego stowarzyszeniu istniały podstawy do ustawowego zwolnienia od podatku od nieruchomości, o którym mowa w art. 7 ust. 1 pkt 5 ustawy z 12 stycznia 1991 r. o podatkach i opłatach lokalnych ${ }^{3}$. Zgodnie z tym przepisem zwalnia się od podatku od nieruchomości grunty, budynki lub ich części zajęte wyłącznie na potrzeby prowadzenia przez stowarzyszenia statutowej działalności wśród dzieci i młodzieży w zakresie oświaty, wychowania, nauki i techniki, kultury fizycznej i sportu, z wyjątkiem wykorzystywanych do prowadzenia działalności gospodarczej, oraz grunty zajęte trwale na obozowiska i bazy wypoczynku dzieci i młodzieży. Organy podatkowe obydwu instancji uznały, że podatnikowi nie przysługiwało zwolnienie z podatku tej części budynku, która w ich ocenie nie była zajęta i wykorzystywana na prowadzenie statutowej działalności wśród dzieci i młodzieży. W glosowanym orzeczeniu kwestią sporną było jednocześnie to, czy cały budynek hali sportowej był w całości faktycznie zajęty na działalność stowarzyszenia.

Tekst jedn. Dz.U. z 2018 r., poz. 800 ze zm., dalej: o.p.

Tekst jedn. Dz.U. z 2014 r., poz. 849 ze zm., dalej: u.p.o.l. 
Sąd I instancji zgodził się ze stanowiskiem organów podatkowych, uznając, że ustalając stan faktyczny, organy te nie naruszyły przepisów prawa, prawidłowo ustalając, że budynek został zajęty na prowadzenie działalności przez stowarzyszenie wyłącznie w części. Jednocześnie sąd, odnosząc się do zasad interpretacji przepisów przewidujących zwolnienie, uznał, że zwolnienie podatkowe jest to przywilej, który jest wyjątkiem od ogólnej zasady powszechności opodatkowania i dlatego przepisy muszą być interpretowane ściśle, a co za tym idzie, to na stronie spoczywa ciężar wykazania przesłanek umożliwiających skorzystanie z przywileju zwolnienia z podatku. Powyższa teza wymaga szczegółowej i krytycznej analizy z uwagi na to, że pogląd sądu w tym zakresie stał się podstawą do nieuprawnionego przyjęcia jako prawidłowych niekorzystnych dla podatnika ustaleń faktycznych dokonanych przez organy podatkowe. Główna teza wyroku była także podstawą do faktycznego pominięcia odniesienia się przez sąd w uzasadnieniu wyroku do oceny przeprowadzonego przez organy podatkowe materiału dowodowego. Teza ta nie znajduje jednocześnie oparcia w treści obowiązujących przepisów oraz aktualnych poglądów doktryny na problem interpretacji przepisów.

\section{3.}

Zgodnie ze znajdującym zastosowanie w sprawie art. 7 ust. 1 pkt 5 u.p.o.l. zwolnione z podatku od nieruchomości są grunty, budynki lub ich części zajęte wyłącznie na potrzeby prowadzenia przez stowarzyszenia statutowej działalności wśród dzieci i młodzieży w zakresie oświaty, wychowania, nauki i techniki, kultury fizycznej i sportu, z wyjątkiem wykorzystywanych do prowadzenia działalności gospodarczej, oraz grunty zajęte trwale na obozowiska i bazy wypoczynkowe dzieci i młodzieży.

Ponieważ analizowane zwolnienie ma charakter przedmiotowy, ze zwolnienia od podatku od nieruchomości korzystają nieruchomości lub ich części stanowiące własność stowarzyszenia oraz stanowiące własności innych podmiotów, o ile stowarzyszenie je faktycznie zajmuje, przy czym bez znaczenia jest tytuł prawny stowarzyszenia do nieruchomości. Przedmiotowe zwolnienie dotyczy jednocześnie nieruchomości, o ile są zajęte 
wyłącznie przez stowarzyszenie, które prowadzi statutowo działalność wśród dzieci i młodzieży w zakresie oświaty, wychowania, nauki i techniki, kultury fizycznej i sportu. Zwolnienie nieruchomości z podatku w oparciu o powołany przepis wymaga zatem, by oprócz faktycznego i wyłącznego zajęcia nieruchomości na wskazane w nim cele, były one także ujęte w statucie stowarzyszenia. W orzecznictwie sądowym podkreśla się słusznie, że nieruchomość jest zajęta na prowadzenie statutowej działalności określonej w art. 7 ust. 1 pkt 5 u.p.o.l. wówczas, gdy jest rzeczywiście wykorzystywana w tym celu ${ }^{4}$.

\section{4.}

Analizując tezę glosowanego wyroku, w pierwszej kolejności należy zdefiniować pojęcie zwolnienia od podatku, a następnie ustalić adekwatność tej tezy do obowiązujących zasad wykładni przepisów. Ponieważ obowiązujące regulacje nie zawierają ogólnej normatywnej definicji zwolnienia podatkowego, należy jednocześnie odwołać się do ustaleń teorii prawa podatkowego. W doktrynie zwolnienia podatkowe definiuje się jako incydentalny element budowy podatku, będący formą redukcji podmiotu bądź przedmiotu podatku ${ }^{5}$. Definiowanie zwolnienia podatkowego w świetle elementów budowy podatku powoduje wątpliwości co do usytuowania zwolnienia podatkowego wśród pozostałych elementów budowy podatku. W teorii proponuje się uznać zwolnienia podatkowe jako składniki hipotezy normy powiązanej z jednym z pozostałych elementów ${ }^{6}$ lub konstruuje się zupełnie odrębną dwuelementową „normę ulgi i zwolnienia podatkowego”, obejmującą tylko ten element budowy podatku ${ }^{7}$ W zależności od przyjętych założeń prawidłowe będzie każde z tych stanowisk, przy

4 Tak np. wyrok WSA w Poznaniu z dnia 9 grudnia 2014 r., III SA/Po 332/14, CBOSA.

5 W. Nykiel, Norma prawa podatkowego a elementy konstrukcji podatku, [w:] J. Małecki, A. Gomułowicz (red.), Ex iniuria non oritur ius. Księga ku czci prof. W. Łqczkowskiego, Poznań 2003, s. 235.

6 W. Nykiel, Zwolnienia i ulgi podatkowe a konstrukcja podatku (wybrane zagadnienia), [w:] B. Brzeziński, J. Głuchowski, C. Kosikowski, R. Mastalski (red.), Księga ku czci Prof. A. Kosteckiego. Studia z dziedziny prawa finansowego, Toruń 1998, s. 179.

7 W. Morawski, Ulgi i zwolnienia w prawie podatkowym, Gdańsk 2002, s. 65-75. 
czym dla potrzeb stosowania przepisów prawa wybór jednego z nich nie ma znaczenia, podobnie jak sam sposób definiowania zwolnienia podatkowego. Definicja „zwolnienia podatkowego” zawarta jest również w regulacjach ogólnego prawa podatkowego, przy czym nie jest to znaczenie przypisywane bezpośrednio odrębnemu terminowi, lecz związane z pojęciem „ulga podatkowa”, dotyczącym faktycznie innej instytucji oraz obowiązującym wyłącznie w zakresie regulacji o.p. W myśl art. 3 pkt 6 o.p. przez ulgę podatkową należy rozumieć przewidziane w przepisach prawa podatkowego zwolnienia, odliczenia, obniżki albo zmniejszenia, których zastosowanie powoduje obniżenie podstawy opodatkowania lub wysokości podatku. Powyższe ujęcie zwolnienia nie ma zatem charakteru uniwersalnego, wpływającego na charakterystykę zwolnień podatkowych w konkretnych podatkach.

Charakteryzując zwolnienia podatkowe, należy zaznaczyć, że nie są one jednorodne. $\mathrm{W}$ doktrynie wskazuje się na różne podziały zwolnień ${ }^{8}$, przy czym dla celów niniejszego opracowania najistotniejszy wydaje się podział w zależności od kryterium celu, jaki zakłada ustawodawca, wprowadzając zwolnienie ${ }^{9}$. W oparciu o to kryterium jako pierwszą grupę w doktrynie wyodrębniono zwolnienia mające charakter „techniczny”, niezwiązany z odejściem od zasady powszechności i sprawiedliwości w opodatkowaniu, ponieważ ich celem nie jest „uprzywilejowanie” jakiejkolwiek grupy podatników, lecz opodatkowanie według racjonalnego modelu (np. zwolnienie z podatku dochodowego uzyskanych odszkodowań). Kolejną wyróżnioną w teorii grupę zwolnień stanowią te, których celem jest różnicowanie obciążeń podatkowych w celu faktycznego zrównania sytuacji podatników z pozostałymi podmiotami w innych niż obciążenia podatkowe dziedzinach (np. zwolnienia podatkowe zakładów pracy zatrudniających osoby niepełnosprawne). Trzecia grupa obejmuje zwolnienia „typowe”, tzn. różnicujące sytuację podatników znajdujących się w podobnych warunkach, których celem jest zachęta do określonych za-

8 Zob. m.in. W. Nykiel, Ulgi i zwolnienia w konstrukcji prawnej podatku, Warszawa 2002, s. 42 i n.

9 Podział przyjęty za: B. Brzeziński, Podstawy wykładni prawa podatkowego, Gdańsk 2008, s. 145-146. 
chowań, najczęściej w sferze działalności gospodarczej. Powyższy podział ma znaczenie praktyczne, ponieważ zakwalifikowanie zwolnienia do jednego ze wskazanych rodzajów może wpływać właśnie na sposób interpretacji przepisów przewidujących zwolnienia podatkowe.

W związku z wykładnią przepisów dotyczących zwolnień podatkowych powstaje wątpliwość w zakresie metod wykładni przepisów, w tym pytanie o to, czy należy przyjąć odmienności w stosunku do interpretacji przepisów przewidujących zwolnienia. Rozstrzygnięcie tej wątpliwości jest istotne w świetle tezy zawartej w głosowanym wyroku. W tym miejscu zaznaczyć należy, że w doktrynie zwrócono uwagę na powtarzający się błędny sposób rozumienia w orzecznictwie tezy o potrzebie ścisłej interpretacji prawa podatkowego w odniesieniu do przepisów wprowadzających ulgi i zwolnienia podatkowe ${ }^{10}$. W teorii wskazuje się, że sądy postrzegają powyższą zasadę jako dyrektywę interpretacji przepisów II stopnia, która nakazuje w sytuacji kilku możliwych rezultatów wykładni przepisów regulujących zwolnienia dokonać wyboru tego, który ma najwęższy zakres, z uwagi na to, że jest „ścisły”, a w efekcie zwykle najmniej korzystny dla podatnika. W doktrynie jednocześnie wykazano słusznie na brak podstaw do formułowania takiego założenia sposobu wykładni przepisów podatkowych ${ }^{11}$. Prawidłowość tezy o wymogu „ścisłej wykładni” jest szczególnie wątpliwa w sytuacji zwolnień o charakterze technicznym oraz tych, których celem jest zrównanie sytuacji podatników zwolnionych z podatku z innymi podmiotami. Analiza orzeczeń sądów prowadzi do wniosku, że przyjęcie zasady „ścisłej wykładni” skutkować może tym, że interpretując przepis, w przypadku którego wykładnia językowa wskazuje na możliwe różne jego znaczenia, sądy w skrajnych przypadkach wyłączają w ogóle możliwości stosowania wykładni funkcjonalnej, bądź w sytuacji wątpliwości interpretacyjnych co do wyniku wykładni językowej z założenia wybierały węższy zakres zwolnień podatkowych ${ }^{12}$. Anali-

10 B. Brzeziński, Podstawy wykładni..., s. 142-147.

11 Tamże.

12 Tak m.in. wyrok NSA z dnia 19 września 2001 r., I SA/Lu 971/00, „Przegląd Orzecznictwa Podatkowego" 2002, nr 3, poz. 98; wyrok NSA z dnia 24 kwietnia 2003 r., SA/Bd 605/03, „Przegląd Orzecznictwa Podatkowego” 2004, z. 6, poz. 129. 
za orzeczeń sądowych potwierdza także dostrzeżoną w doktrynie tendencję, by mając możliwość wyboru zakresu zwolnienia, w sytuacji wyboru jego węższego znaczenia nie poprzestawać na przyznaniu, iż to węższe znaczenie jest prawidłowe, tj. adekwatne do stanu sprawy, lecz dodatkowo wskazywać, że wybór ten uzasadnia konieczność ścisłej wykładni przepisów dotyczących zwolnień ${ }^{13}$.

W aktualnym orzecznictwie sądowym odchodzi się natomiast słusznie od wskazanego powyżej, błędnego ujęcia zasady „ścisłej wykładni przepisów dotyczących zwolnień” i rozumie się ją w sposób prawidłowy, tj. jako wykładnię „dokładną”, „adekwatną”, „niewychodzącą poza literalne i klarowne znaczenie interpretowanych przepisów”, „niedowolną” oraz „nieuzupełnianą o treści, których przepis nie zawiera” ${ }^{14}$. Aktualnie odrzuca się w orzecznictwie możliwości wybiórczego stosowania metod wykładni, tzn. z wykluczeniem niektórych jej metod i wskazanie na wymóg kompleksowej wykładni prawa podatkowego (uwzględniając przy tym poglądy doktryny $)^{15}$, z jednoczesnym zaznaczeniem prymatu wykładni językowej ${ }^{16}$. Współcześnie orzeczenia dotyczące zwolnień w podatku od nieruchomości coraz częściej nie powielają także formułki o zwolnieniach jako wyjątku od zasady powszechności, równości i sprawiedliwości opodatkowania, lecz w drodze stosowania poszczególnych metod wykładni ustalane jest znaczenie przepisu, często ze wskazaniem wprost na konieczność odrzucenia zawężającego wyniku wykładni językowej $^{17}$. Podejście powyższe zasługuje na pełną aprobatę ${ }^{18}$.

13 B. Brzeziński, Podstawy wykładni..., s. 143.

14 Tak np. wyrok WSA w Poznaniu z dnia 27 sierpnia 2014 r., III SA/Po 1497/13, CBOSA; wyrok WSA w Szczecinie z dnia 14 kwietnia 2005 r., I SA/Sz 919/04, CBOSA.

15 Wyrok WSA w Olsztynie z dnia 4 września 2008 r., I SA/Ol 163/08, CBOSA; wyrok WSA we Wrocławiu z dnia 11 maja 2006 r., I SA/Wr 708/05, CBOSA.

16 Przykładowo wyrok NSA z dnia 13 sierpnia 2010 r., II FSK 450/09, CBOSA.

17 Zob. wyrok WSA w Krakowie z dnia 8 września 2009 r., I SA/Kr 1103/09, CBOSA; wyrok WSA w Gdańsku z dnia 5 lutego 2013 r., I SA/Gd 1275/12, CBOSA.

18 Zob. szerzej P. Majka, Wykładnia przepisów regulujq̨cych ustawowe zwolnienia w podatku od nieruchomości w orzecznictwie sq̨ów administracyjnych [w:] W. Miemiec (red.), Finanse samorzq̨dowe po 25 latach samorzq̨ności. Diagnoza i perspektywy, Warszawa 2015, s. 435-445. 


\section{5.}

Powyższe ustalenia pozwalają zakwestionować prawidłowość zarówno uznania, że art. 7 ust. u.p.o.l. zawiera „przywilej”, jak i tego, że utrwalone w doktrynie i orzecznictwie jest, iż zwolnienie musi być interpretowane ściśle, a co za tym idzie, to na stronie spoczywa ciężar wykazania przesłanek umożliwiających skorzystanie z przywileju zwolnienia z podatku.

W pierwszej kolejności jako niemające podstaw należy uznać posłużenie się w głosowanym wyroku na określenie zwolnienia od podatku terminem „przywilej”. Termin „przywilej” współcześnie nie występuje w języku prawnym oraz brak podstaw, by posługiwać się nim obecnie w języku prawniczym ${ }^{19}$. Jeżeli również uwzględnić powołane wyżej rodzaje zwolnień, to wydaje się, że zwolnienia podatkowego polegającego na zwolnieniu od podatku od nieruchomości powierzchni budynku zajętej przez stowarzyszenia nie można traktować jako „przywileju” w znaczeniu, w jakim jest ono nadawane w języku potocznym („szczególne uprawnienie” „prawo do korzystania ze szczególnych względów w jakimś

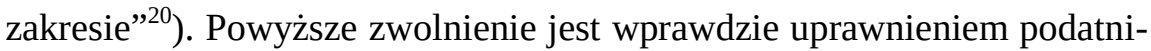
ka, redukującym przedmiot opodatkowania, jednak brak podstaw do uznania, że ma ono charakter „szczególny”. Zwolnienie to jest bowiem obligatoryjne (tj. nie jest stosowane na zasadzie uznania przez organ podatkowy i nie zależy także od woli podatnika) oraz wynika z ustawy, a motywem jego wprowadzenia było zwolnienie powierzchni nieruchomości, która nie jest faktycznie wykorzystywana komercyjnie, lecz realizuje cel, który dodatkowo ujęty został w treści art. 68 ust. 5 Konstytucji RP z 2 kwietnia 1997 r. $^{21}$, przewidującego obowiązek władz publicznych popierania rozwoju kultury fizycznej zwłaszcza wśród dzieci i młodzieży. Kwestionując poprawność określania zwolnień podatkowych jako „przywilejów”, wskazać należy jednocześnie na zasadność posługiwania się w języku prawnym przykładowo pojęciem „nagrody w prawie” jako bodźcem stwarzającym sytuację motywującą do przestrzegania norm

\footnotetext{
Szerzej B. Brzeziński, Podstawy wykładni..., s. 143.

M. Szymczak (red.), Słownik języka polskiego, t. II, Warszawa 1979, s. 1065.

Dz.U. z 1997 r. Nr 78, poz. 483 ze zm.
} 
prawnych $^{22}$. Termin nagrody w prawie nie odnosi się jednak do instytucji analizowanych zwolnień podatkowych oraz z samego charakteru instytucji jako tego rodzaju „nagrody” nie można wywodzić konieczności specjalnej (ścisłej) wykładni przepisów w ujęciu, w jakim dokonał tego sąd w glosowanym orzeczeniu.

Nie ma również podstaw, by z konieczności ścisłej wykładni przepisów regulujących zwolnienia podatkowe wywodzić, że to na stronie spoczywa ciężar wykazania przesłanek umożliwiających skorzystanie ze zwolnienia z podatku. Postępowanie podatkowe ma charakter wyłącznie gabinetowy, natomiast w toku postępowania dowodowego organ zobowiązany jest do przestrzegania m.in. zasady prawdy obiektywnej, zasady czynnego udziału strony w postępowaniu oraz zasady swobodnej oceny dowodów, co ma gwarantować ochronę strony ${ }^{23}$. Istota postępowania podatkowego co do zasady wyklucza zatem obowiązek dowodzenia przez podatnika okoliczności faktycznych. Jednocześnie podatnik, nie przedstawiając dowodów, które nie są w posiadaniu organu, musi oczywiście liczyć się z ewentualnym negatywnym skutkiem prawnym. Nie zwalnia to jednak organów podatkowych $\mathrm{z}$ obowiązku dowodzenia wynikającego z przepisów postępowania podatkowego określonego w art. 122, art. 187 $\S 1$ oraz art. 191 o.p. Zwolnienie organów podatkowych z obowiązku ustalenia prawdy obiektywnej prowadziłoby bowiem do niezastosowania ustawowego zwolnienia, które jest obligatoryjne, pomimo że faktycznie występowałyby przesłanki do jego przyjęcia. Nie można zatem przyjąć sformułowanej w glosowanym wyroku tezy wynikania ciężaru dowodzenia przez podatnika przesłanek zwolnienia z zasady wymogu ścisłej wykładni prawa.

Wydaje się, że sformułowanie przez sąd powyższej tezy miało na celu stworzenie podstaw do oceny jako prawidłowych ustaleń organów podatkowych, co do których w związku z twierdzeniami podatnika powstawały wątpliwości $\mathrm{w}$ zakresie naruszenia zasady prawdy obiektywnej.

22 Zob. J. Niesiołowski, Nagrody jako element systemów normatywnych, „Państwo i Prawo" 1983, nr 11, s. 70 i n.

23 B. Brzeziński, M. Masternak, O tak zwanym ciężarze dowodu w postępowaniu podatkowym, „Przegląd Podatkowy” 2004, nr 5, s. 56 i n. 
Umożliwiło to następnie nieuznanie zarzutów skargi z odwołaniem się w sposób lakoniczny do tego, że spółka nie przedstawiła w toku postępowania przed organami podatkowymi „wiarygodnych dowodów, które dałyby podstawę do stwierdzenia, że powierzchnia nieruchomości zajęta na potrzeby prowadzonej przez Stowarzyszenie statutowej działalności jest większa niż ustaliły to organy w swych decyzjach”.

6.

Zastrzeżenia odnośnie do zgodności z art. 141 § 4 ustawy z dnia 30 sierpnia 2002 r. - prawo o postępowaniu przed sądami administracyjnymi ${ }^{24}$ budzi dokonana w glosowanym orzeczeniu ocena przeprowadzonego postępowania dowodowego, na co zwrócił uwagę również NSA w wyroku z dnia 20 kwietnia 2018 r. $^{25}$, rozpoznając skargę kasacyjną. Oceniając przeprowadzone postępowanie dowodowe w zakresie zajęcia budynku na działalność stowarzyszenia, sąd I instancji uznał, że ,jednoznaczne, wiarygodne zeznanie pracowników A. S.A. dały podstawę do ustalenia, że zajęcia sportowe z młodzieżą prowadzone były jedynie w części parteru budynku (hali 38). W świetle spójnych i wzajemnie korespondujących ze sobą zeznań pracowników A. SA nie można skutecznie czynić zarzutów organom, że nie dały wiary zeznaniom J. S., który prowadził zajęcia sportowe”.

Naruszenie przez sąd I instancji unormowania art. $141 \S 4$ p.p.s.a. w rozpatrywanej sprawie, na co wskazuje lektura uzasadnienia glosowanego judykatu, wydaje się oczywiste. Zgodnie z tym przepisem (zdanie pierwsze) uzasadnienie wyroku sądu administracyjnego powinno zawierać zwięzłe przedstawienie stanu sprawy, zarzutów podniesionych w skardze, stanowisk pozostałych stron, podstawę prawną rozstrzygnięcia oraz jej wyjaśnienie. Jeżeli (zdanie drugie) w wyniku uwzględnienia skargi sprawa ma być ponownie rozpatrzona przez organ administracji, uzasadnienie powinno ponadto zawierać wskazania co do dalszego postępowania.

24 Tekst jedn. Dz.U. z 2018 r., poz. 1302, dalej: p.p.s.a.

25 II FSK 1041/16, CBOSA. 
Jak zauważa się w literaturze przedmiotu, uzasadnienie rozstrzygnięcia sądowego nie jest instytucją wtórną w stosunku do postępowania przeprowadzonego przed sądem administracyjnym, ale przeciwnie - błędne uzasadnienie orzeczenia może prowadzić do niezgodnego z prawem załatwienia sprawy, obarczone zaś nim orzeczenie co do zasady nie odpowiada prawu. Do sytuacji, gdy wadliwość uzasadnienia wyroku może stanowić usprawiedliwioną podstawę skargi kasacyjnej, należy zaliczyć tę, gdy owo uzasadnienie nie pozwala na kontrolę kasacyjną orzeczenia. Dzieje się tak zwłaszcza wtedy, gdy nie ma możliwości jednoznacznej rekonstrukcji podstawy rozstrzygnięcia ${ }^{26}$.

Teza o wydaniu glosowanego wyroku WSA w Rzeszowie z naruszenia art. $141 \S 4$ p.p.s.a. może być zatem słusznie postawiona, gdyż uzasadnienie tego wyroku sporządzone zostało w sposób uniemożliwiający kontrolę instancyjną. W szczególności wyrok nie zawiera wszystkich z wymienionych w tym przepisie elementów konstrukcyjnych, nie pozwalając w sposób jednoznaczny ustalić przesłanek, jakimi się on kierował. Treść uzasadnienia orzeczenia, co już powiedziano, powinna przede wszystkim umożliwić prześledzenie toku rozumowania sądu i poznanie racji, które stały za rozstrzygnięciem o zgodności lub braku zgodności z prawem zaskarżonego aktu. Nie jest bowiem możliwa kontrola orzeczenia, którego elementy wskazane $\mathrm{w}$ art. $141 \S 4$ p.p.s.a. formułuje się w sposób lakoniczny, niejasny czy nielogiczny. Przy tym wada uzasadnienia musi mieć wpływ na sentencję orzeczenia ${ }^{27}$.

Sporządzone uzasadnienie glosowanego wyroku w części obejmującej ustalenia stanu faktycznego dotyczącego powierzchni budynku zajętej na prowadzenie działalności statutowej przez podatnika z pewnością nie odpowiada zasadom przewidzianym w art. $141 \S 4$ p.p.s.a. W cytowanym już uprzednio wyroku z dnia 20 kwietnia 2018 r. NSA stwierdził bowiem, że sporządzone uzasadnienie zaskarżonego wyroku, „uniemożliwia odniesienie się do postawionych w skardze kasacyjnej zarzutów. Podstawą do

26 J.P. Tarno, Prawo o postępowaniu przed sq̨dami administracyjnymi. Komentarz, Warszawa 2012, s. 365-366.

27 Np. wyroki NSA z dnia 25 kwietnia 2018 r., II GSK 4334/17; z dnia 13 stycznia 2016 r., I OSK 994/14, CBOSA. 
określenia faktycznej powierzchni budynku, w której odbywały się zajęcia sportowe, była opinia biegłego. Niemniej jednak należy podnieść, że biegły sporządził jedynie pomiary wskazanej mu części budynku. Źródłem natomiast tego wniosku dowodowego, nie mogło być ustalenie, czy faktycznie w tej części odbywały się zajęcia sportowe. Dowodem, który pozwalał na ustalenie, w jakiej części odbywały się zajęcia sportowe, nie mogły być również oględziny budynku, które nastąpiły już po 2013 r., czyli okresie opodatkowania, będącym przedmiotem postępowania. Na podstawie oględzin można jedynie stwierdzić, jaki stan istnieje w dacie ich dokonywania. Dlatego też z dowodów przeprowadzonych przez organy podatkowe na te okoliczności, miarodajnymi mogły być jedynie uznane przez organy za wiarygodne zeznania pracowników A. S.A. Mieli ono mieć bezpośrednią wiedzę, w jakim zakresie budynek był wykorzystywany przez Stowarzyszenie w 2013 r. W tym zakresie ocena dowodów z przesłuchania tych świadków przeprowadzona przez sąd pierwszej instancji, sprowadza się jedynie do stwierdzenia, że były one jednoznaczne, spójne, wzajemnie korespondujące ze sobą i tym samym wiarygodne”. NSA podniósł przy tym, że sąd I instancji nie podał jednak, „jacy świadkowie zeznawali i co konkretnie z ich zeznań wynikało. Lakoniczne i ogólnikowe stwierdzenia zawarte w uzasadnieniu zaskarżonego wyroku, nie pozwalają Naczelnemu Sądowi Administracyjnemu na dokonanie oceny prawidłowości zaskarżonego rozstrzygnięcia w tej części. Sformułowania sądu pierwszej instancji można odnieść do jakiegokolwiek postępowania. Podobne uwagi dotyczą wywodu WSA w Rzeszowie, co do odmowy wiarygodności zeznań świadka J. S.”

\section{7.}

Reasumując, glosowany wyrok nie zasługuje na aprobatę ze względu na wadliwość przedstawionej w nim argumentacji dotyczącej stosowania przepisów regulujących zwolnienia podatkowe. Pośrednim skutkiem błędnych założeń odnośnie do wykładni przepisów było naruszenie unormowań obowiązującej procedury sądowo-administracyjnej, które określają reguły prawidłowo sporządzonego uzasadnienia wyroku. 


\section{Bibliografia:}

Brzeziński B., Masternak M., O tak zwanym ciężarze dowodu w postępowaniu podatkowym, „Przegląd Podatkowy” 2004, nr 5, s. 56-59.

Brzeziński B., Podstawy wykładni prawa podatkowego, ODDK, Gdańsk 2008.

Gomułowicz A. (red.), Ex iniuria non oritur ius. Księga ku czci prof. W. Łqczkowskiego, UAM, Poznań 2003.

Majka P., Wykładnia przepisów regulujq̨cych ustawowe zwolnienia w podatku od nieruchomości w orzecznictwie sq̨dów administracyjnych, [w:] W. Miemiec (red.), Finanse samorzqdowe po 25 latach samorzqdności. Diagnoza i perspektywy, Wolters Kluwer, Warszawa 2015.

Morawski W., Ulgi i zwolnienia w prawie podatkowym, ODDK, Gdańsk 2002.

Niesiołowski J., Nagrody jako element systemów normatywnych, „Państwo i Prawo" 1983, nr 11, s. 70-74.

Nykiel W., Norma prawa podatkowego a elementy konstrukcji podatku, [w:] J. Małecki, A. Gomułowicz (red.), Ex iniuria non oritur ius. Księga ku czci prof. W. Łqczkowskiego, Printer, Poznań 2003.

Nykiel W., Ulgi i zwolnienia $w$ konstrukcji prawnej podatku, ABC, Warszawa 2002.

Nykiel W., Zwolnienia i ulgi podatkowe a konstrukcja podatku (wybrane zagadnienia), [w:] B. Brzeziński, J. Głuchowski, C. Kosikowski, R. Mastalski (red.), Księga ku czci Prof. A. Kosteckiego. Studia z dziedziny prawa finansowego, TNOiK, Toruń 1998.

Szymczak M. (red.), Słownik języka polskiego, Tom II, Państwowe Wydawnictwo Naukowe, Warszawa 1979.

Tarno J. P., Prawo o postępowaniu przed sq̨dami administracyjnymi. Komentarz, LexisNexis Polska, Warszawa 2012. 